\title{
A reappraisal of the 1968 Valle del Belìce seismic sequence (western Sicily): a case study of intensity assessment with cumulated damage effects
}

\author{
Raffaele Azzaro*,1, Maria Serafina Barbano ${ }^{1,2}$, Andrea Tertulliani ${ }^{1}$, Claudia Pirrotta ${ }^{2}$ \\ (1) Istituto Nazionale di Geofisica e Vulcanologia, Italy \\ (2) Dipartimento di Scienze Biologiche, Geologiche e Ambientali, Università di Catania, Italy
}

Article history: received July 30, 2019; accepted October 28, 2019

\begin{abstract}
In 1968, six earthquakes with magnitude between 5.1 and 6.4 destroyed or heavily damaged several towns in the Valle del Belice (western Sicily), causing some three hundred fatalities. There have been some critical issues in the intensity assessment however in the macroseismic studies produced over the years, since the MCS scale was used as an estimation of shaking rather than a representation of the damage scenario; in practise, intensity was assigned for each earthquake of the sequence disregarding the effect of the cumulative damage. The case-study of the 2016-17 earthquakes in Central Italy reflected the difficulty in estimating the intensity in localities repeatedly hit by strong shocks, producing macroseismic parameters (epicentre, magnitude) inconsistent with the instrumental ones. As for the 1968 Valle del Belice sequence, the Parametric Catalogue of Italian Earthquakes CPTI15 reports the macroseismic parameters, owing to the inadequacy of the seismic network operating in Italy in that period. Aware of the issues related to epicentre locations and magnitudes calculated by the existing macroseismic datasets, here we propose a reappraisal of the 1968 earthquakes following a methodology tested during the 2016-17 seismic sequence in Central Italy. By a new analysis of the primary sources, we reconstruct the evolution of the damage scenario during the sequence and assess intensity by using the European Macroseismic Scale EMS-98; the new macroseismic parameters are finally compared with the ones of the CPTI15 catalogue. Lastly, we propose a procedure for minimizing the magnitude overestimation in case of seismic sequences, based on the computation of the total seismic moment $\mathrm{M}_{0}$.
\end{abstract}

Keywords: Historical seismology, intensity, Macroseismics, 1968 Belìce earthquakes, Sicily.

\section{Introduction}

The 1968 earthquakes in Western Sicily represent one of the most important sequences in the seismic history of Italy in the second half of the $20^{\text {th }}$ century. From 14 to 25 January, six shocks with equivalent moment magnitude $\mathrm{M}_{\mathrm{w}}$ ranging from 5.1 to 6.4 struck the Valle del Belìce, a territory in between the provinces of Agrigento, 


\section{Raffaele Azzaro et al.}

Trapani and Palermo (Figure 1). The seismic period lasted about a year and the primitive seismic network operating at that time in Sicily recorded more than 350 earthquakes [De Panfilis and Marcelli, 1968; Valle, 1969]. At the end of the seismic sequence an area roughly $2000 \mathrm{~km}^{2}$ proved devastated: there were some 300 deaths, four towns were destined to be rebuilt in entirely different sites (Gibellina, Montevago, Poggioreale, Salaparuta), while others were to be reconstructed in the same locations but greatly modified in their urban layouts (Partanna, Salemi, Santa Margherita, Santa Ninfa).

The impact on the territory and society, mostly in terms of resilience, was enormous, so much so as to become, together with the case of Irpinia after the 1980 earthquakes, a symbol of a problematic and very lengthy reconstruction [Guidoboni and Valensise, 2011]. This can be ascribed to a number of factors, the main ones being the poor quality of buildings, the number of shocks occurring in nearby areas during a very short timespan and, last but not least, the condition of poverty in this underdeveloped and rather withdrawn part of Sicily [Traina, 1978].

The state of knowledge of the 1968 earthquakes, like others occurring in Italy in those years, is closely related to the poor development of the Italian seismic network. In Sicily, only three seismic stations were operating with almost 'primitive' typology of instruments - mechanical Wiechert type seismometers - located at Palermo, Messina and Catania.

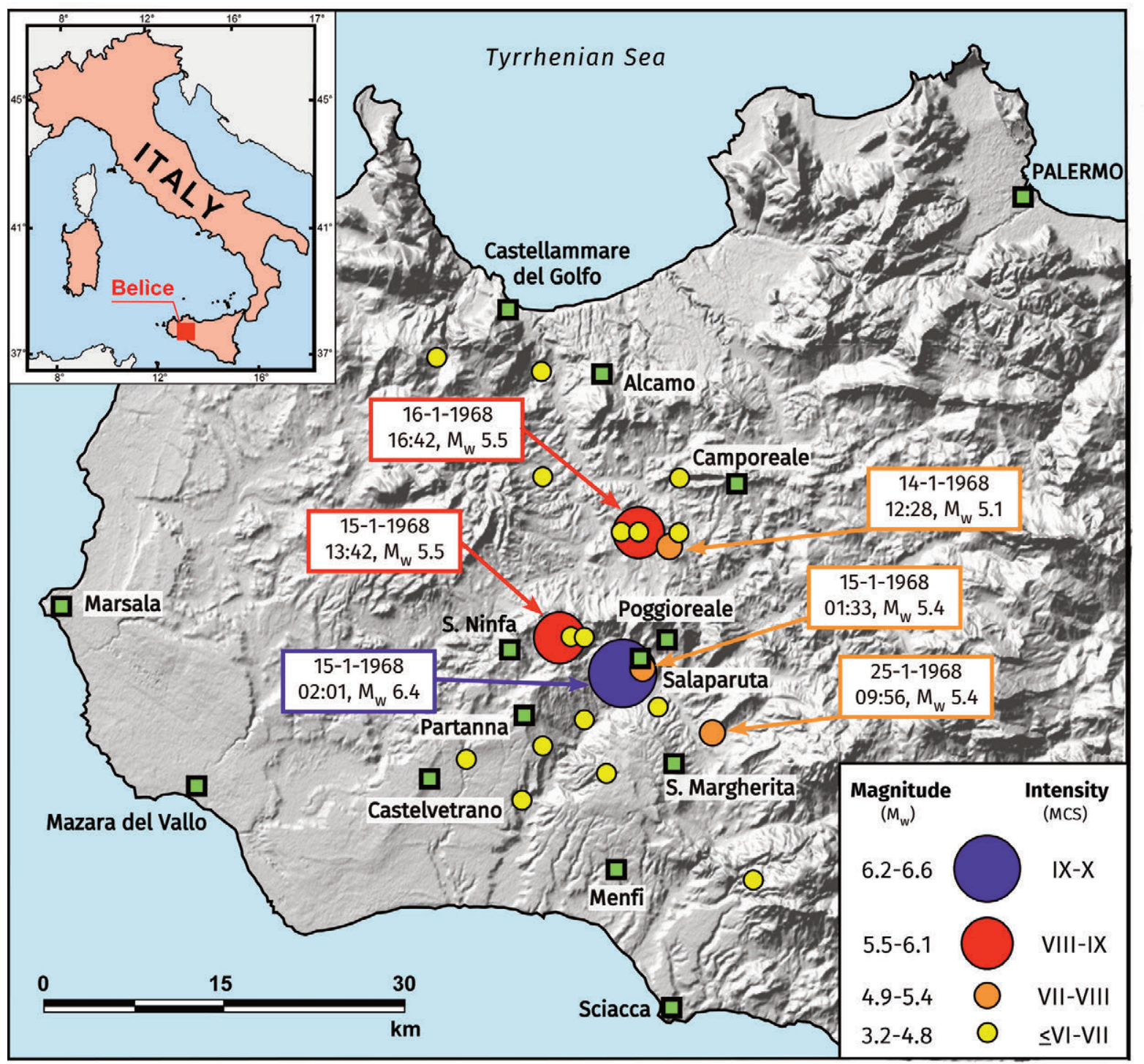

Figure 1. Location of the 1968 Valle del Belìce earthquakes according to the CPTI15 earthquake catalogue [Rovida et al., 2016]. Magnitude $M_{W}$ is the equivalent moment magnitude obtained by macroseismic data. 
Another two seismometers were installed in Trapani and Agrigento after January 25, effectively when all the strong events had already occurred; the instrumental analysis was consequently affected by large uncertainties with rather unstable earthquake parameters [De Panfilis and Marcelli, 1968; Bottari, 1973]. Similarly, also the macroseismic survey of the 1968 earthquakes proved difficult not only for the continuous strong shocks that quickly modified the damage scenario, but also for the dire emergency situation as well as for "secondary" factors such as landslides, collapsed buildings and damaged bridges that interrupted the road network [AA.VV., 1968]. In addition, the "traditional" macroseismic practice privileged the idea of determining the intensity of the single shocks of the sequence, losing sight of the issues on cumulative effects due to multiple earthquakes.

The studies by Barbano et al. [1980], Cosentino and Mulone [1985] and Guidoboni et al. [2018] followed this line as well, so that there is an evident inconsistency in intensities that were assessed in the localities repeatedly hit by damaging shocks. We believe, in fact, that previously damaged buildings perform poorly, so that a relatively "weak" aftershock may cause disproportionate amounts of damage, thus producing errors in the intensity evaluation. The recent case study of the 2016-17 seismic sequence in Central Italy emphasized this aspect, with the obvious implication that the resulting macroseismic parameters (epicentre, magnitude) are considerably inconsistent with those derived by instrumental data [Graziani et al., 2017; Rossi et al., 2019].

In this paper, we propose a reappraisal, in terms of macroseismic analysis, of the 1968 Valle del Belice earthquakes following the same approach used in Central Italy in 2016-17. We re-analyse the primary sources to reconstruct the evolution of the damage scenario during the sequence, then assess intensity by using the European Macroseismic Scale [EMS-98, Grünthal, 1998] and finally, we compare the macroseismic parameters calculated by these new data with the ones reported in the CPTI15 earthquake catalogue [Rovida et al., 2016].

\section{Revaluating intensity: methodological approach}

Seismologists and engineers dealing with macroseismic surveys during seismic sequences are increasingly aware of the impact of the cumulative damage effects on the assessment of intensity [Tertulliani et al., 2012; Grimaz and Malisan, 2016; Graziani et al., 2019]. This emerged definitively after the 2016-17 earthquakes in Central Italy, where the macroseismic campaign was carried out considering the issue of the damage progression after each strong shock [Rossi et al., 2019]. An important result of this accurate field activity, albeit particularly time-consuming, is that the damage progression observed in a locality repeatedly struck by the earthquakes can be influenced by the space-time evolution of the seismic sequence (i.e. epicentre migration) in addition to the deterioration of the strength of the buildings.

Although distinguishing damage effects due to different shocks could theoretically be possible for isolated case studies (i.e. at the scale of a single building), the complexity of situations found during a survey indicates that the only way to make the intensity assessment viable is by examining the cumulative effects. This situation also occurred during the 1968 Valle del Belice seismic sequence, characterised by a number of earthquakes causing heavy damage in a roughly $2000 \mathrm{~km}^{2}$ area.

To follow the evolution of damage for as many of shocks and places as possible, we performed a retrospective analysis of the primary sources with the purpose of simulating an a-posteriori survey carried out day by day. To this end, we used a wide spectrum of sources (Figure 2): coeval scientific papers, technical reports, macroseismic questionnaires [Cartoline macrosismiche, 1968], archive documents, socio-anthropological and architecture books, local diaries, and newspapers [see the complete list of the documentary materials in Appendix 1 of Azzaro et al. 2020, this volume].

As regards the press, at that time there were three regional newspapers - L'Ora and Giornale di Sicilia printed in Palermo, and La Sicilia in Catania - which published detailed articles daily on the earthquakes' effects and rescue operations; other significant information made it into print in national magazines and newspapers. In addition, as for other modern earthquakes, photographs, videos and TV reports represent a huge source of documentation, making the 1968 Valle del Belice seismic sequence the first to be documented in a genuinely mediatic way in Italy. Much of this material comes from local people.

Practically, the approach we used can be summarised in the following phases: (i) unpacking information referred to each single town or village, classifying relevant data day by day and integrating information coming from different sources; (ii) evaluating the coherence of data; (iii) reconstructing the evolution of the damage scenario during the sequence; (iv) assessing intensity and, (v) calculating earthquake parameters. 


\section{Typology of sources}

- scientific literature

- official reports/archive documents

- local historiographic studies

- newspapers

- photos and videos

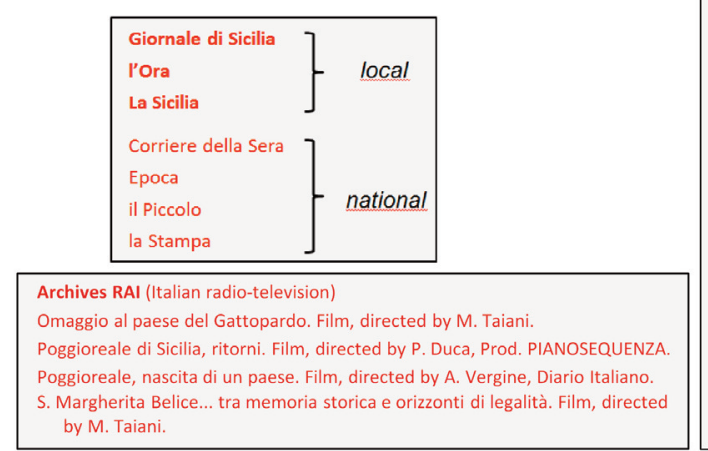

Aloisio, F. (1986). Storia di Poggioreale (Sicilia). Tip. Priulla, Palermo, 318 pp. Assessorato Territorio ed Ambiente, Regione Siciliana (1988): La Sicilia dentro l'immagine. Compagnia Generale Ripreseaeree Ed., Parma, 109 pp.

Bosi, C., R. Cavallo and V. Francaviglia (1973). Aspetti geologici e geologico-tecnici del terremoto della Valle del Belíce del 1968. Mem. Soc. Geol. It., 12, 81-130.

Cangelosi, L. (1977). Addio, Gibellina. Arti Grafiche Campo, Alcamo (TP), 155 pp.

Cannata, D., M. Costantino, A. D'Amore, G. Gregorio, M. Irti, A. Pasta, D. Priolo, V. Stura and G. Miglietti (1968). Missione di studio nelle zone terremotate della Sicilia Occidentale. In "L'industria delle costruzioni". Rivista tecnica dell'ANCE", settembre-ottobre 1968, Roma.

Cusumano, A. (2003). La strada maestra. Memoria di Gibellina Comune di Gibellina, Graf. CampoAlcamo, $130 \mathrm{pp}$.

Cosentino P. and A. Mulone (1985). The Belice earthquake of January 15, 1968. In Atlas of isoseismal maps of Italian earthquakes, D. Postpischl (Ed.), CNR, Quad. Ric. Scie., 114B, 150-151. Cartoline macrosismiche (1968). Ufficio Centrale di Meteorologia e di ecologia A 150 ria, Servizio Sismico, Roma.

De Panfilis, M. and L. Marcelli (1968). ॥ periodo sismico della Sicilia occidentale iniziato il 14 Gennaio 1968. Ann. Geofis., 21, 79 pp.

Filangeri, C. (2001). Ricordi tra immagini e ... versi. Ed. Associazione Culturale Filangeri di Cutò, S. Margherita di Belice, $191 \mathrm{pp}$.

Gangemi, G. and La Franca, R. (1979). Centri storici di Sicilia. Inventario di protezione dei sistemi urbani delle provincie di Trapani, Agrigento, Caltanissetta, Enna. Vittorietti Ed., Palermo, vol. 1, 98 pp.

Graffagnino, B. (1992). Salaparuta ieri e oggi '92. Arti Grafiche Siciliane, Palermo, 588 pp.

L'opera di Protezione Civile nella Sicilia occidentale colpita dal terremoto 14 gennaio - 31 marzo 1968. Quaderni di Protezione Civile, special issue 1968, 68 pp.

Marino, G.C. (Ed.) (1968). '68 terremoto in Sicilia. Andò Editori, Palermo, 140 pp.

Marino, G.C. (Ed.) (1968). '68 terremoto in Sicilia. Ando Editori, Palermo, $140 \mathrm{pp}$. Gattopardo. Ed Scuderi, S.M. Belice, 723 pp?

Terremoto in Sicilia (1969). L'intervento del Ministero dei lavori Pubblici per le zone sinistrate. Litopress, $41 \mathrm{pp}$.

Traina, M. (1978). Valle del Belice (introduzione alla storia di 10 anni di terremoto). Tip. Fiamma Serafica, Palermo, $414 \mathrm{pp}$

Vella, E. (2003). Poggioreale di Sicilia tra civiltà contadina e odierna società. Prova d'autore Ed., Tip. Artestampa, Catania, $199 \mathrm{p}$

\section{8

Figure 2. Example of typologies of primary sources used in this study; the arrow indicates the prevailing typologies of sources over time.

Lastly, it should be stressed that the 1968 Valle del Belìce case study represents a particularly suitable opportunity to apply the EMS-98. Indeed, the construction features of buildings can be clearly recognised by visiting the ruins of the abandoned settlements (especially Poggioreale) or the deserted neighbourhoods still visible inside some towns of the area (e.g. Salemi, Santa Margherita, Menfi, Partanna). For this reason, we made a survey to observe typologies and features of the structures in the area most struck by the 1968 earthquakes, and to acquire objective elements for evaluating the buildings vulnerability according to the EMS-98 guidelines [Grünthal, 1998]; some examples will be discussed in chapter 4 .

\section{Analysis of the sources}

In the second step of our study, we critically analysed the collected sources starting from newspapers, which report useful information on the effects in both the epicentral area and the surrounding localities; moreover, they describe how the earthquakes were felt in the rest of Sicily. The newspaper Giornale di Sicilia, printed in nearby Palermo, is, for example, particularly rich in data, providing detailed descriptions of damage, figures of unusable buildings and deaths, and other information of interest. The first three days of the seismic sequence (i.e. 14, 15 and 16 January) are documented with a great deal of data, while afterwards all the newspapers mostly report on the slowness of the rescue and the hardship faced by people in the camps (weather conditions were adverse, with snow and rain).

We unpacked the information of damage described by the newspapers in different localities in order to reconstruct the evolution of damage during the seismic sequence. In doing this, we also used those rare photographs documenting the damage progression during the sequence (Figure 3).

It is worth pointing out that the newspapers generally described an overview of the effects, cumulating the damage due to more shocks in a single day, so that it is impossible to distinguish them individually. As a result, we obtained a daily picture of damage referring to the shocks occurring on 14, 15, 16 and 25 January, and a final scenario evaluated after the sequence ended (news items were published until the end of March). 
Regarding the scientific literature, the coeval reports by Bosi et al. [1968], Cannata et al. [1968], De Panfilis and Marcelli [1968], Haas and Ayre [1969], provide a very detailed description of the final seismic scenario in the damaged localities, together with accurate technical notes on building characteristics and seismo-geological effects [Bosi et al., 1973]. They surveyed the damaged area soon after the sequence, before the bulldozers raised collapsing buildings to the ground and removed the ruins. For this reason, their observations are extremely interesting and useful to check the reliability of information reported in the newspapers; in doing so, we found a surprisingly good agreement between these two different types of sources. Other data of interest come from local historiographic studies and archive documents as well as from the numerous photographic and video documentation.
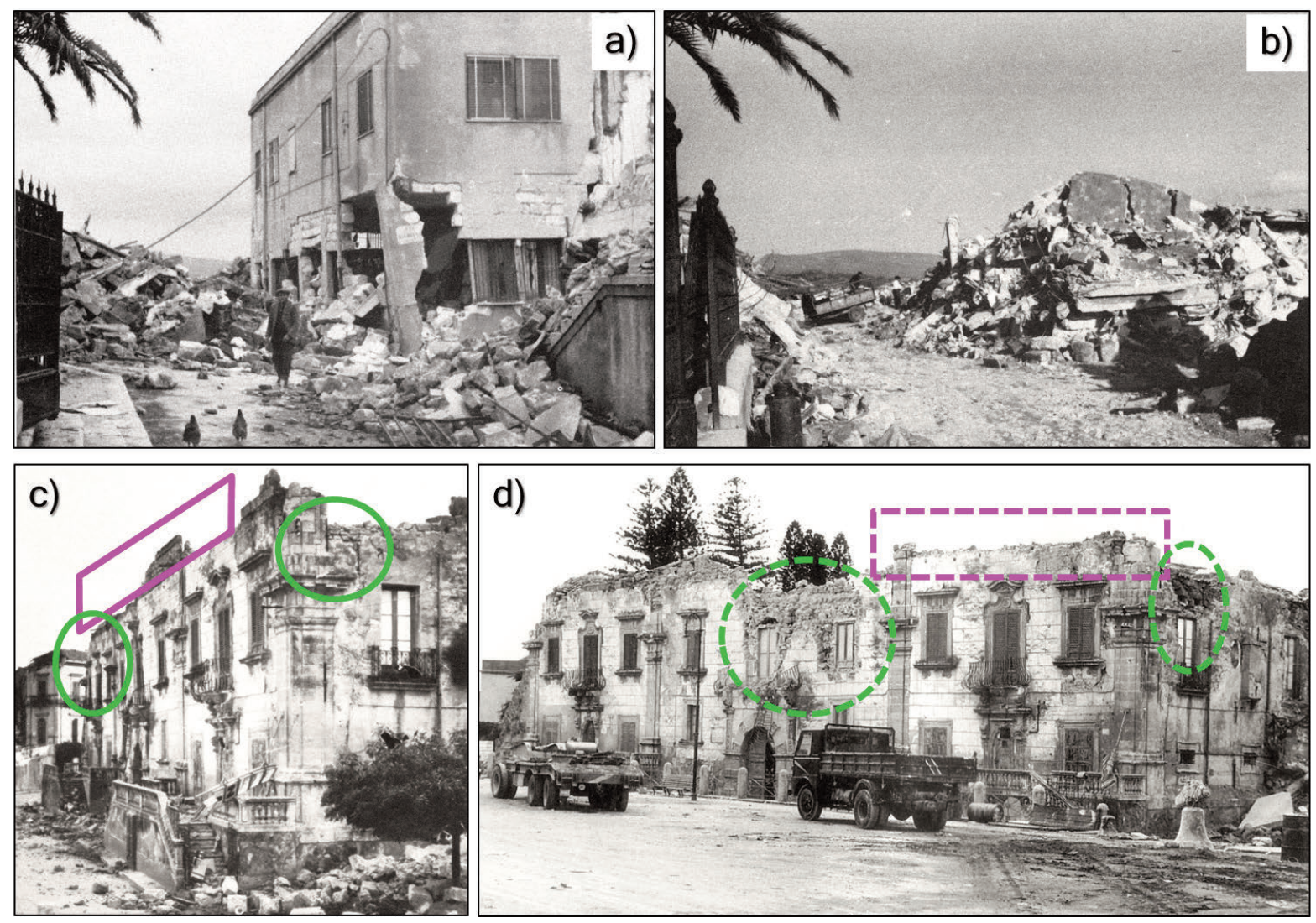

Figure 3. Example of evolution of damage documented by photographs. Top: Salaparuta, a) the Class $\mathrm{C}$ building of the boarding school on 24 January, with degree 4 damage on the ground floor; b) total collapse (degree 5) on 25 January (photos by Graffagnino, 1992). Bottom: Santa Margherita, c) the Filangeri di Cutò Palace (Class B) after 15 January suffered degree 4 damage; note the cornice (purple box) and the upper parts of the edifice (green circles) being heavily damaged (photo by Marino, 1968); d) the Palace partially collapsed on 25 January: note the cornice has entirely fallen down and serious failure can be seen in the upper part of the building (above the windows) (photo by Filangeri, 2001).

\section{Building vulnerability in the epicentral area}

In the Valle del Belice the urbanization at the time of the 1968 earthquakes was mainly organized around latifundia of Western Sicily, with villages and small towns consisting of traditional constructions and a few more important buildings [Gangemi and La Franca, 1979]. In a report commissioned by the Committee on Earthquake Engineering Research of the USA National Research Council [Haas and Ayre, 1969], published after a detailed survey in early February 1968, we read: "There were no anti-earthquake regulations in the building codes and the old buildings in the villages and farms were readily subject to collapse...”. It soon became clear that the building stock of the area was definitely inadequate to withstand significant shaking. 


\section{Raffaele Azzaro et al.}

Fifty years after the 1968 earthquakes many ruins are still visible and in some cases also well preserved, so we undertook a field-trip to the abandoned villages and the old neighbourhoods of the towns reconstructed in the same site, in order to determine the prevailing typologies of the building stock. The picture obtained was then compared with the building typologies and used materials that are described in detail for various localities by Bosi et al. [1968] and Cannata et al. [1968]. This step was essential to consider the correct EMS-98 vulnerability classes [Grünthal, 1998] in assessing intensity. In short, the association typology versus vulnerability of buildings for the Valle del Belice area, can be described as follows:

Class A: structures built with materials easily available on site, mostly soft calcarenites, made up of coarse masonry with irregular or sometimes roughly squared stones, assembled with poor mortar that tends to deteriorate over the years (Figure $4 \mathrm{a}-\mathrm{c}$ ). In some cases, these old buildings, one to two stories, had been poorly retrofitted, or simply modified, by replacing the original timber roofs with heavy reinforced concrete (RC) ones, but without the adequate strengthening of the vertical elements nor the addition of tie rods or other connection elements between floors and walls (Figure 4d).
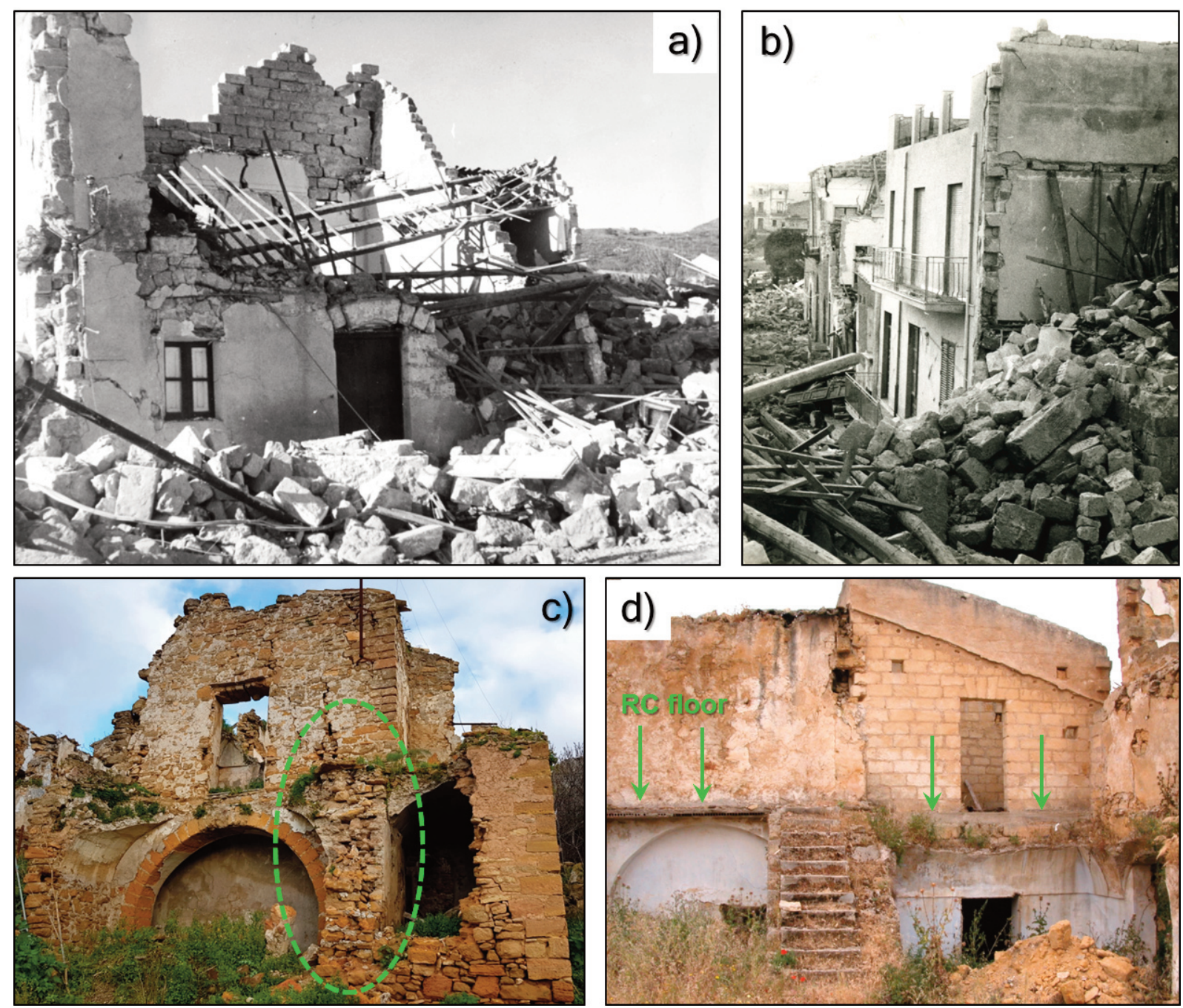

Figure 4. Example of buildings with vulnerability Class A. Collapse of structures built with squared blocks of soft calcarenites assembled with little mortar: a) Poggioreale; b) Santa Margherita (photos by L'Ora, 1968). c) Santa Margherita, masonry with very irregular stones, assembled with very poor mortar and d) interventions of elevation with RC slab floors and heavy blocks of calcarenites above a weak masonry (when not specified, photos are by the authors of this study). 
Class B: masonry buildings with bearing-walls of good quality, typically roughly dressed calcarenites, one to two stories, with squared stones and generally good mortar, sometimes with RC slab floors and tie-rods (Figure 5a-b).

Class C: RC buildings, two to four stories, especially in the outskirts built-up since the mid-1960s. However, these structures were rare at that time and did not include any kind of earthquake-resistant design or reinforcement (Figure 5c-d).
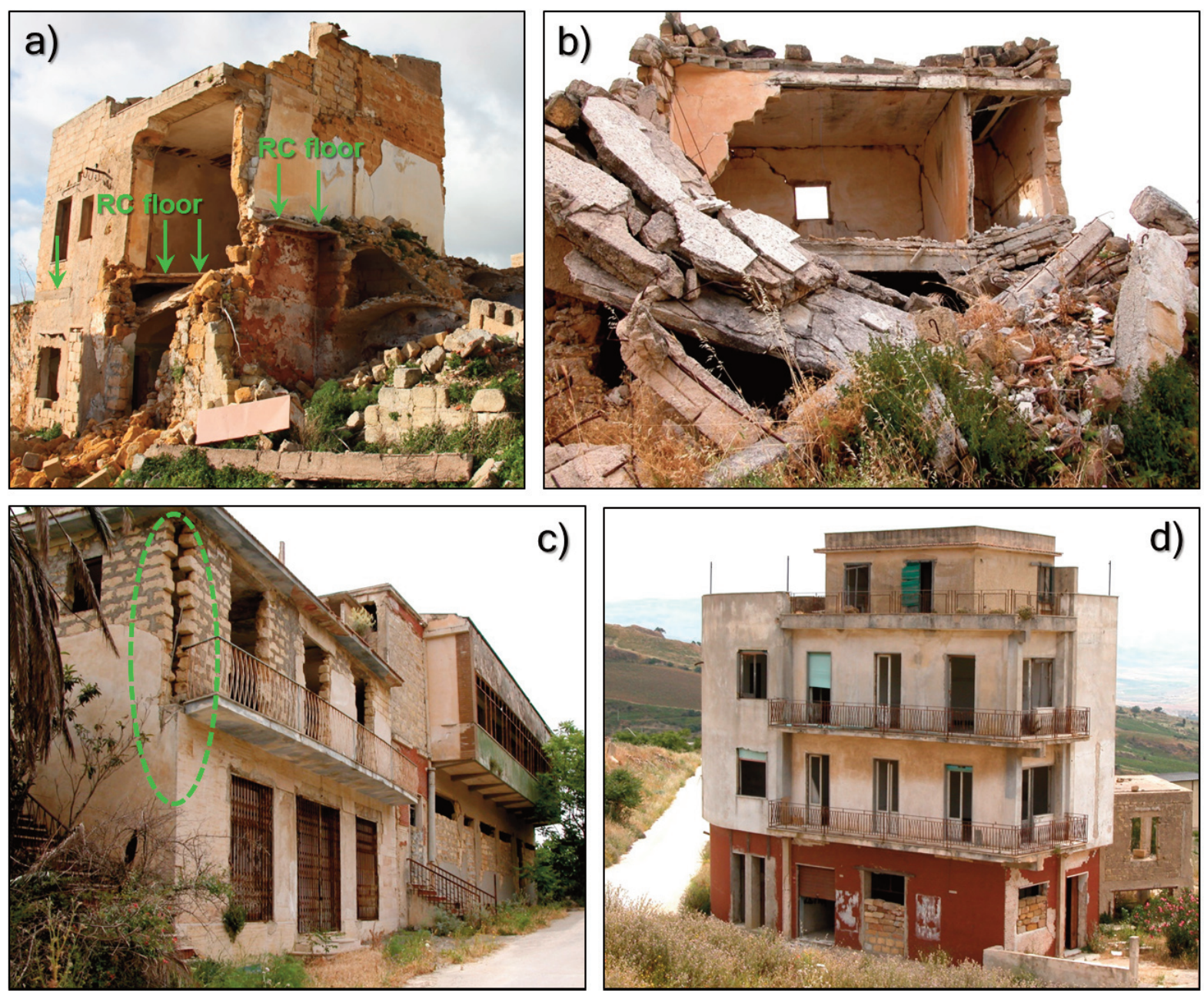

Figure 5. Top: examples of buildings with vulnerability Class B. a) Santa Margherita: structure characterised by numerous interventions that significantly modified the masonry over time; note the RC slab floors positioned at different levels; b) Salaparuta, mixed structure showing a heavy RC slab not sustained by the ground floor masonry. Bottom: example of buildings with vulnerability Class C in Gibellina: c) the first floor was added without any structural connection (green ellipse) to the underlying RC frame; d) the only RC building still standing today, suffered moderate damage (degree 3 ) though without earthquake-resistant design.

The above general classification of the building stock nonetheless shows inconsistent situations throughout the towns of the epicentral area as well as within the same locality. The overall building characteristics observed in a given site may be responsible, at least partly, for different levels of damage also in very short distances between nearby villages. In particular, we observed a condition of high building vulnerability in Montevago (in the downtown area) and Santa Margherita (in the northernmost part of the old town, around the St. Vito church). In these sectors, masonry consists of soft calcarenites with very irregular texture and scarce or absent mortar. Moreover, the buildings appear weakened by frequent interventions of elevation with massive stones and RC slab floors. The same situation 


\section{Raffaele Azzaro et al.}

is documented by the photographic and video documentation for Gibellina (completely demolished) and Salaparuta (partially demolished but still visible in the northern part of the settlement) (Figure 5b). Conversely, we found a condition of lower building vulnerability in Poggioreale (the old village is relatively well preserved after fifty years of abandonment), Salemi and Partanna, where buildings generally display a more firm masonry, with reinforcement elements as tie rods and massive cornerstones (Figure 6).

Finally, as regards the monumental buildings, we noted that churches and palaces display a wide range of structural features, with the main ones having been built with massive stones; however, all of them were destroyed or heavily damaged. Since damage suffered by these kinds of structures should be managed with care according to the guidelines of the EM-98 scale [Grünthal, 1998], we consider it as a complementary information for the overall scenario.
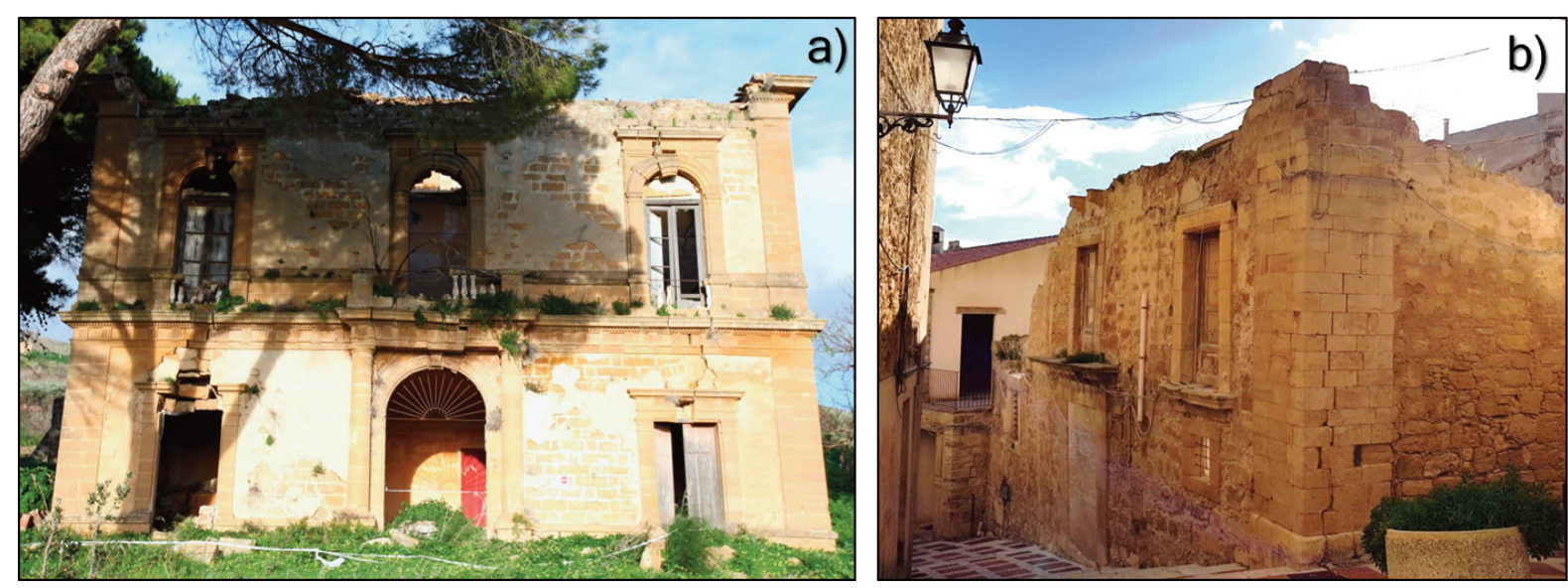

Figure 6. a) Poggioreale, a solid masonry structure with massive stone (Class C) still standing after fifty years of abandonment; b) Salemi, example of a vulnerability Class B building with massive cornerstones; note that the upper part of the house was demolished to make safe access to the street.

\section{Results}

From the interpretative point of view, the main limitation in reconstructing the 1968 macroseismic dataset is that this seismic sequence was characterised by the repetition of damaging events day by day (particularly on 14, 15 and 16 January) as well as by the occurrence of strong earthquakes within a few hours or even tens of minutes. This led to a fragmentary picture of information, difficult to describe and containing inconsistencies as well. Also De Panfilis and Marcelli [1968] - the main source of information for the subsequent studies by Barbano et al. [1980], Cosentino and Mulone [1985], Guidoboni et al. [2018] - report generic information on damage produced by the individual shocks in several localities, admitting that the maximum intensities of the various shocks are calculated from the instrumental magnitudes; moreover, they do not provide any intensity data points.

In our analysis, we therefore tried to interpret the collected information as a daily scenario, assessing the cumulative intensity for 14, 15, 16, and 25 January. In all, we evaluated the intensity for 169 localities distributed throughout the sequence of events. Compared to the previous studies [Cosentino and Mulone, 1985; Guidoboni et al., 2018], for the 15 January earthquakes we have a lower number of intensities but a direct comparison should be avoided given the different assumptions adopted in the interpretation of data (individual shocks vs. cumulated effects in the same day).

\subsection{Intensity assessment and damage progression}

This section presents the evolution of the 1968 seismic sequence in terms of macroseismic intensity, taking into account the cumulative effects of damage. All intensities are expressed in EMS-98. Time is indicated in GMT format; 
as for the magnitude, hereafter we refer to the instrumental values $\left(\mathrm{M}_{\mathrm{wi}}\right)$ reported in the CPTI15 catalogue (see the complete version of file CPTI15_v1.5.xls), while the equivalent $\mathrm{M}_{\mathrm{w}}$ reported in the catalogue is obtained by using the macroseismic data points (MDPs) of previous studies [for the method see Rovida et al., 2016].

On 14 January, 3 earthquakes with $4.7 \geqslant \mathrm{M}_{\mathrm{W}} \geqslant 5.1$ occurred from 12.28 to 15.48 , accompanied by other minor shocks (three of them being felt by people). Gibellina, Salaparuta and Poggioreale suffered substantial damage to class A buildings (Table 1): a few with partial collapse, large cracks in most walls and failure of non-structural single elements. This scenario is consistent with intensity 7 EMS-98. Very slight damage (I 5-6) occurred in Alcamo, Calatafimi, Camporeale, Menfi, Montevago, Partanna, Santa Margherita, Santa Ninfa and Sambuca (Figure 7a).

\begin{tabular}{|c|c|c|c|c|}
\hline Locality & 14 January & 15 January & 16 January & 25 January \\
\hline Gibellina & 7 & 9 & $9-10$ & 10 \\
\hline Salaparuta & 7 & 9 & $9-10$ & 10 \\
\hline Montevago & $5-6$ & $8-9$ & 9 & $9-10$ \\
\hline Poggioreale & $6-7$ & $8-9$ & $8-9$ & 9 \\
\hline Santa Margherita & $5-6$ & 8 & $8-9$ & 9 \\
\hline Partanna & 6 & 8 & 8 & $8-9$ \\
\hline Menfi & $5-6$ & $7-8$ & 8 & 8 \\
\hline Santa Ninfa & $5-6$ & 8 & 8 & $8-9$ \\
\hline Salemi & $4-5$ & $7-8$ & $7-8$ & 8 \\
\hline Contessa Entellina & & $7-8$ & 8 & 8 \\
\hline Calatafimi & $5-6$ & $6-7$ & & $7-8$ \\
\hline Sambuca di Sicilia & $5-6$ & $6-7$ & 7 & $7-8$ \\
\hline Castelvetrano & 5 & 6 & 7 & 7 \\
\hline Camporeale & 6 & 7 & 7 & 7 \\
\hline Alcamo & $5-6$ & 6 & 6 & $6-7$ \\
\hline San Giuseppe Jato & & $5-6$ & 6 & $6-7$ \\
\hline Palermo & $3-4$ & $5-6$ & 6 & 6 \\
\hline Trapani & 5 & 5 & & 6 \\
\hline Termini Imerese & & & & $5-6$ \\
\hline Agrigento & 3 & 4 & & 5 \\
\hline
\end{tabular}

Table 1. Example of intensity (EMS-98) increase due to the damage progression in the most heavily struck towns of the Valle del Belice and other surrounding localities.

On 15 January, the first significant earthquake struck with $\mathrm{M}_{\mathrm{wi}} 5.3$ at 01.33 , followed by the mainshock of the seismic period, $\mathrm{M}_{\mathrm{wi}}$ 5.7, at 02.01 ; three strong aftershocks with $4.8 \geqslant \mathrm{M}_{\mathrm{wi}} \geqslant 5.4$ and other minor events occurred the same day. As a result, Gibellina and Salaparuta suffered the collapse of many of the already damaged buildings (I 9); Poggioreale and Montevago, which the day before was slightly damaged, were very heavily damaged (I 8-9). At Santa Margherita (similarly to Montevago), Santa Ninfa and Partanna heavy damage occurred (I 8); finally, severe damage (I 7-8) was also caused in Menfi and Salemi (Figure 7b). Many localities around were moderately or slightly damaged.

On 16 January, another $\mathrm{M}_{\mathrm{wi}} 5.3$ shock at 16.42 caused the collapse of the few buildings left standing in Gibellina, Salaparuta and Montevago (I 9); very heavy damage (I 8-9), again, occurred at Poggioreale and Santa Margherita, whereas Partanna, Menfi, Santa Ninfa and Contessa had further partial collapses (Class A buildings, I 8). The damage area extended to the North as far as Palermo (I 6) (Figure 7c). 


\section{Raffaele Azzaro et al.}

The earthquakes occurring the following days are not clearly documented in terms of description of the effects, since the central sector of the Valle del Belice appeared more or less destroyed. A little information comes from some localities located in the periphery of this area, where the level of damage (and hence intensity) still remained moderate. For example, on 20 January at 12.21, an earthquake (magnitude unknown) caused further damage in Calatafimi (I 7), whereas on 21 January at 02.39 another shock of just $\mathrm{M}_{\mathrm{wi}} 4.4$ damaged Giuliana (I 6-7).

On 25 January, at 09.56 , the last strong event, $\mathrm{M}_{\mathrm{wi}} 5.2$, raised to the ground the remains of Gibellina and Salaparuta (I 10) and, partially, Montevago (I 9-10). Poggioreale and Santa Margherita were struck to a lesser degree (I 9) as well as Partanna and Santa Ninfa (I 8-9); Menfi did not modify the previous damage scenario (I 8) but moderate damage appeared in several localities little damaged by the previous earthquakes (Figures 7d, 8). The entire felt areas of the events are reported in the Appendix.

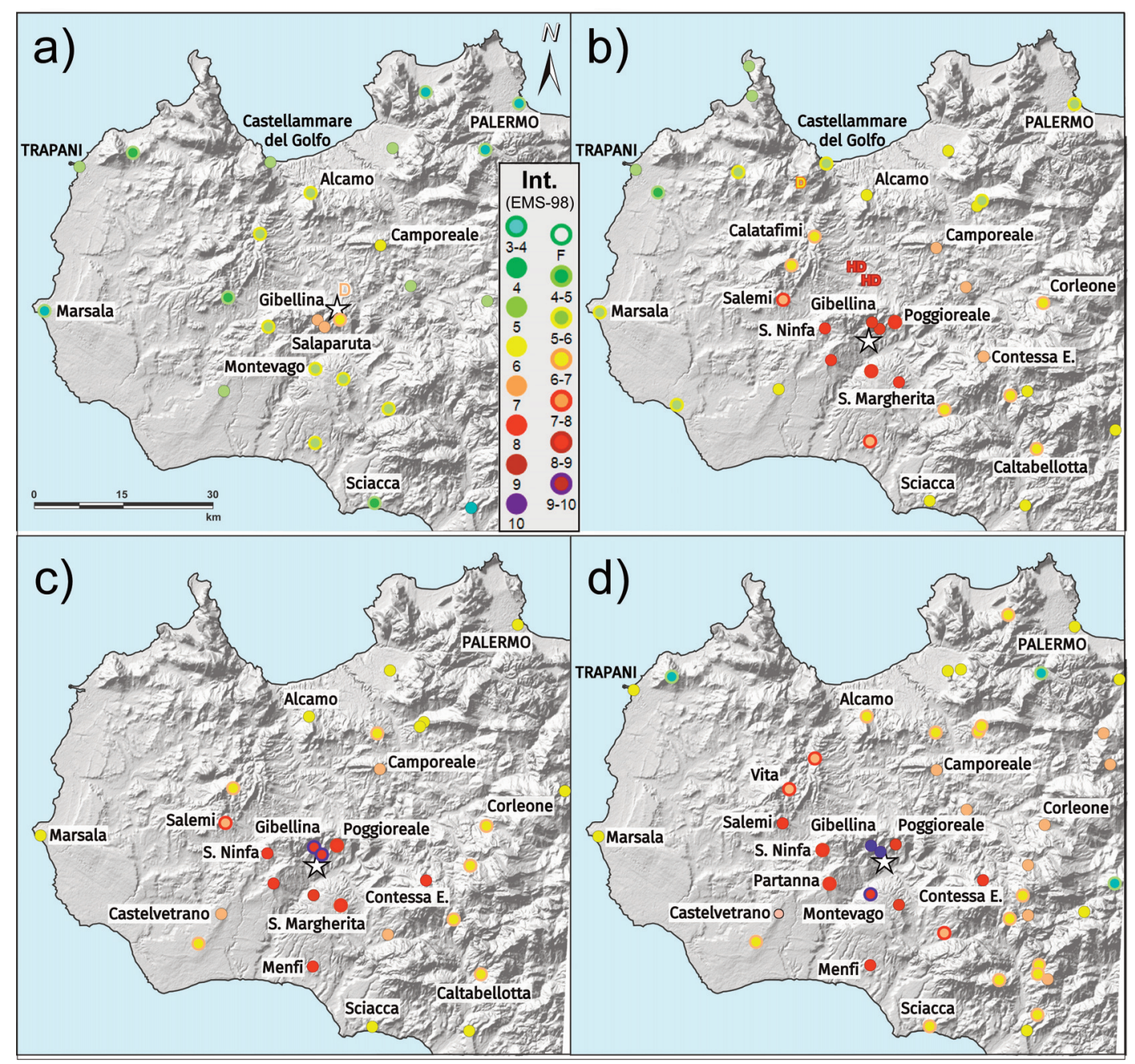

Figure 7. Intensity maps referring to the progressively increasing macroseismic effects of the main earthquakes occurring during the 1968 Valle del Belìce sequence: a) 14 January; b) 15 January; c) 16 January; d) 25 January.

In the following weeks, some other shocks caused further collapses to the ruins, such as on 12 February at 16.26 $\left(\mathrm{M}_{\mathrm{wi}}\right.$ 4.6) and 30 March at $13.39\left(\mathrm{M}_{\mathrm{L}} 4.6\right.$, not revised) but, given the situation, it is indeed a kind of effect which has little sense to evaluate in terms of macroseismic intensity.

In conclusion, the intensities in the localities of the epicentral area increased day by day, almost reaching the maximum as early as 15 January (Poggioreale, Partanna and Santa Ninfa), 16 January (Contessa Entellina) and, definitively, in most of them on 25 January. Nevertheless, this result reflects the uncertainty in the intensity assessment, which is intrinsic in this kind of study and cannot be discarded. 

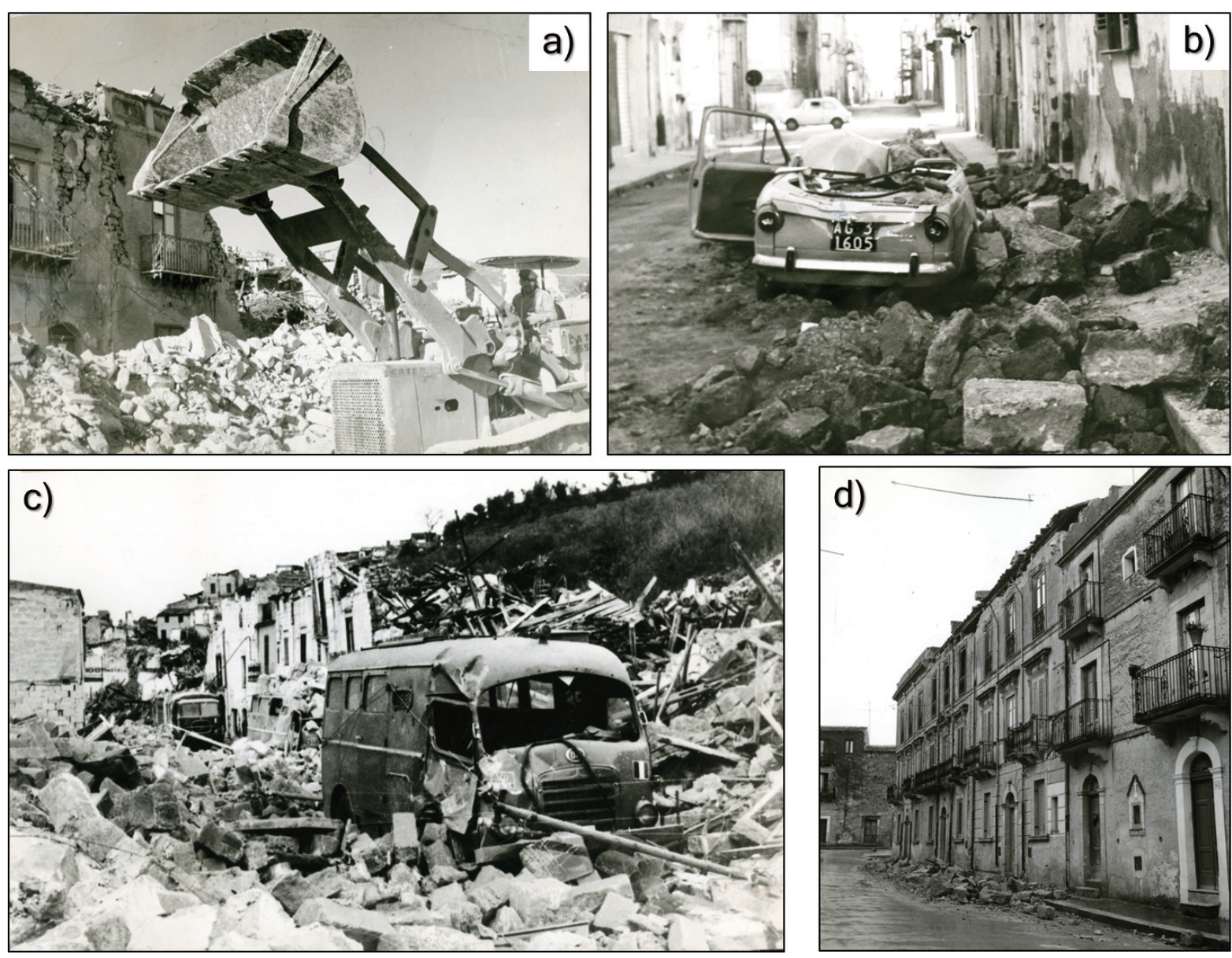

Figure 8. a) Salaparuta, ruins were raised to the ground by bulldozers; b) Menfi, partial collapses meant highly dangerous situations but luckily there were no victims; c) Gibellina, the last collapses due to the 25 January earthquake also led to casualties, including deaths in the rescue teams; d) Salemi, collapse of the eaves and damage to the upper part of the edifice (photos by L'Ora, 1968).

\subsection{Cumulative damage scenario}

The process of intensity assessment described above has been validated by generating a final cumulative damage, i.e. we theoretically find the same situation in which the authors of the coeval scientific reports were during their surveys (Table 2). To this end, we defined a sort of "aggregated macroseismic field" by selecting the maximum value of intensity assessed for each locality during the seismic sequence (only for the damaged ones, see the last column in Table 1 and Appendix). Then we compared our cumulative intensities with the damage scenarios described at the end of the sequence by Bosi et al. [1968] and Cannata et al. [1968] and interpreted them in terms of macroseismic intensity. As a result, there is an excellent match between the two estimations except for Partanna and Santa Ninfa, for which our evaluation provides higher intensity values (7-8 vs. 8-9 in both cases).

The comparison with data by De Panfilis and Marcelli [1968] is rather problematic and has to be made in a different way. These authors report a long list of localities with the damage percentages officially defined by the Civil Engineering Office. Although these data are theoretically suitable for estimating intensity - number of housing units, \% destroyed, \% heavily damaged, \% cracked - De Panfilis and Marcelli [1968] preferred to calculate a "damage index". This was probably determined by both too much synthetic information for the macroseismic use and little consistency of data, as we verified in trying to estimate intensity through these percentages. 
Raffaele Azzaro et al.

Localities Cumulative damage scenario

The earthquake effects were such that they radically changed the original landscape. The houses,

Gibellina, once standing on the slopes of the hill, have collapsed one on another and the town appeared

Salaparuta as a colossal landfill from which here and there emerge the remains of buildings more or less spared by the earthquake [Bosi et al., 1968]. No RC buildings (type C) collapsed due to the earthquake, even though some of them have damage to their essential elements.

Most buildings of Class A were destroyed, particularly those higher than one storey. Class B buildings generally collapsed in the central and older part of the town, where they were adjacent to each other with a common separating wall. There was only heavy damage in the areas where

Montevago buildings stood isolated. Reinforced concrete buildings (Class C) showed minor damage. A few partially collapsed; those of lower height were generally cracked [Bosi et al., 1968]. This appears particularly evident, comparing the damage suffered by the central and oldest part of the town (Class A and B buildings) to the peripheral and more modern part (mainly Class C buildings).

Poggioreale All the existing buildings in the town were severely damaged, but only a few of them, especially towards the western end of the town, collapsed completely.

Most of the ancient constructions (Class A) partially collapsed. Mainly along the north-eastern edge

Santa Margherita of the inhabited area, overlooking the Valle del Belice. A large number of edifices of this type, built on "calcareous tuff" which constitutes the subsoil of the inhabited area and is partly obtained in caves dug into the same "tuff", bank, have been totally destroyed by the earthquakes [Bosi et al., 1968].

Table 2. Final damage scenario of the most damaged localities in the 1968 seismic sequence.

For example, Gibellina and Salaparuta are classified as 100\% destroyed, which would mean a higher value than degree 10 EMS-98 evaluated by us; the same percentage is applied to Poggioreale, still standing and open to visitors, that we assessed at 9 EMS-98. However, it appears clear that the three categories of damage defined by De Panfilis and Marcelli [1968], are too generic with respect to the damage grades in the EMS-98 classification. On the other hand, we cannot exclude that the political choice of abandoning and resettling a town, as in the case of Gibellina, Salaparuta, Montevago and Poggioreale, had to be supported by technical evaluations for practical reasons in the post-earthquake reconstruction.

Another issue is that the percentages of damage given by the Civil Engineering Office refer to the whole municipal territory; this leads to evident discrepancies. For instance, damage suffered in Alcamo and Monreale is quite different (lower) with respect to that observed in some parts of their very large municipal territories, especially for the settlements located to the south and very close to the maximum damage area.

For these reasons, we preferred to consider only the localities for which low percentages of damage are reported by De Panfilis and Marcelli [1968], which are generally located far from the epicentral area and therefore the assessment of intensity is less influenced by the increase of damage. The criteria defined for the evaluation of the EMS-98 intensities are shown in Table 3.

Intensity

\begin{tabular}{ccc}
5 & $<10 \%$ & \\
\hline $5-6$ & $\geqslant 10 \%$ & $<10 \%$ \\
\hline 6 & $10-30 \%$ & $<10 \%$ \\
\hline $6-7$ & $>30 \%$ & $10-20 \%$
\end{tabular}

Table 3. Conversion of the percentages of damage reported by De Panfilis and Marcelli [1968] in terms of EMS-98. 
We obtained a good agreement with the estimates based on newspapers or other sources; however, in order to keep the interpretation of information as coherent as possible, we used data from De Panfilis and Marcelli [1968] only for the localities not considered in the aforementioned sources.

\subsection{New macroseismic parameters}

The macroseismic parameters of the four strongest shocks have been computed from the MDPs, reported in the Appendix, through the Boxer method [Gasperini et al., 2010]; the equivalent magnitude $\mathrm{M}_{\mathrm{w}}$ is obtained by using the last calibration adopted in the CPTI15 catalogue [Rovida et al., 2016]. Results are shown in Table 4.

\begin{tabular}{|c|c|c|c|c|c|c|}
\hline \multirow{2}{*}{ Date } & \multicolumn{2}{|c|}{ Epicentre } & \multirow{2}{*}{$\mathbf{I}_{0}$} & \multirow{2}{*}{$\begin{array}{c}\mathrm{M}_{\mathrm{W}} \\
\text { (this study) }\end{array}$} & \multirow{2}{*}{$\begin{array}{c}\mathrm{M}_{\mathrm{Wi}} \\
\text { (instrumental) }\end{array}$} & \multirow{2}{*}{$\begin{array}{c}\Delta \text { Epicentre } \\
(\mathbf{k m})\end{array}$} \\
\hline & Lat $\mathbf{N}$ & Long E & & & & \\
\hline 14 January 1968 & 37.801 & 13.000 & 7.0 & $5.04 \pm 0.35$ & $5.15 \pm 0.27$ & 5.7 \\
\hline 15 January 1968 & 37.753 & 12.970 & 9.0 & $5.97 \pm 0.18$ & $5.67 \pm 0.23$ & 6.0 \\
\hline 16 January 1968 & 37.756 & 12.981 & 9.5 & $6.17 \pm 0.27$ & $5.27 \pm 0.21$ & 11.5 \\
\hline 25 January 1968 & 37.756 & 12.995 & 10 & $6.34 \pm 0.22$ & $5.15 \pm 0.21$ & 8.8 \\
\hline Cumulative & 37.756 & 12.995 & 10 & $6.33 \pm 0.17$ & - & \\
\hline
\end{tabular}

Table 4. Macroseismic parameters (magnitudes and epicentres) computed for the four main earthquakes and comparison with the instrumental $\mathrm{M}_{\mathrm{Wi}}$ reported in the CPTI15 catalogue [Rovida et al., 2016], obtained by data from the International Seismological Centre (ISC); $\Delta$ Epicentre indicates the distance between macroseismic and instrumental locations. The parameters referring to the cumulative damage scenario, are also reported.

As a general consideration, it may be observed that the macroseismic parameters are increasingly affected by the cumulative effect of damage during the sequence; in practice, epicentre and magnitude of the first earthquake (14 Jan.) can be considered quite reliable, but a little less for those of the event occurring the next day (15 Jan.). This is evident from the fact that these epicentres differ significantly from each other while those of the following shocks (16, 25 Jan.) show variations inside the errors. The comparison with the instrumental parameters ( $\mathrm{M}_{\mathrm{wi}}$ in Table 4) suggests the same conclusion also for the magnitude values, which diverge considerably from 16 January onwards.

We also calculated the macroseismic parameters of the cumulated MDPs by selecting, for each locality, the highest value of intensity assigned for the different shocks; in this way, we reproduced the overall earthquake scenario on the territory. Note that the obtained epicentre and magnitude do not differ from the ones of the 25 January event, i.e. the MDPs of this last event actually reflect the cumulative effect of intensity.

The distribution of the macroseismic and instrumental locations is shown in Figure 9, together with the epicentres in the CPTI15 catalogue calculated by previous macroseismic datasets [Barbano et al., 1980; Guidoboni et al., 2018]. We can note that: i) the 14 January shock appears located north of the Gibellina-Poggioreale alignment, consistently with the position of the instrumental epicentre; ii) the following events moved southward, among the most damaged towns of the Valle del Belice. The apparent migration of the epicentres along an E-W direction is probably the effect of the geographic distribution of the localities which were most affected by the progression of damage during the sequence.

In conclusion, though the actual location of the 1968 earthquakes presents wide margins of uncertainty due to the irresolvable problems of the macroseismic and instrumental data, the epicentres proposed here appear closer to the instrumental ones than the previous ones indicated in the CPTI15 catalogue. 


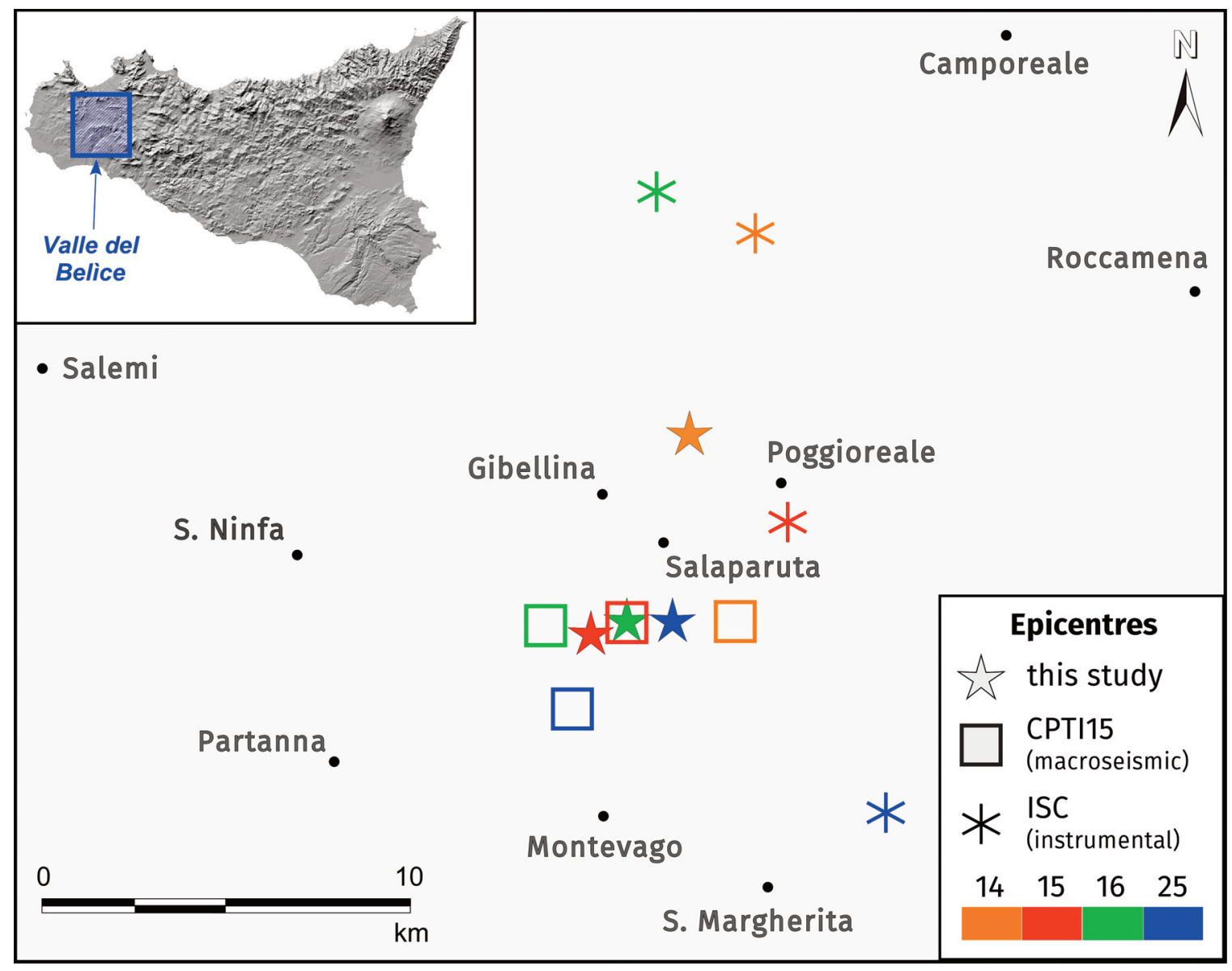

Figure 9. Macroseismic epicentres obtained in this study (Table 1) compared with the locations reported in the CPTI15 catalogue.

Regarding the issue of the increasing values of macroseismic $\mathrm{M}_{\mathrm{w}}$ in Table 4, implying an evident overestimation of the earthquakes during the sequence, we tried to obtain new estimations by calculating the seismic moment $\mathrm{M}_{0}$. Assuming that after the last strong shock on 25 January most of the fault displacement associated with the 1968 seismic sequence was released and given that the MDPs of Figure $7 \mathrm{~d}$ virtually provide the final (cumulative) damage scenario, we believed that the relevant $\mathrm{M}_{\mathrm{w}}$ could represent the total $\mathrm{M}_{0}$ released at the end of the sequence with a good approximation.

As shown in Table 5, by applying the formula of Hanks and Kanamori [1979], we first calculated the seismic moments of the events from the $\mathrm{M}_{\mathrm{W}}$ values previously obtained through the Boxer code, and then we subtracted from the $\mathrm{M}_{0}$ for a given day those of the previous shocks. For instance, from the $\mathrm{M}_{0}$ obtained for the 15 January, we subtracted the $\mathrm{M}_{0}$ calculated for the previous 14; again, from the $\mathrm{M}_{0}$ for the 16 January, we subtracted the moments of 15 and 14 January, etc. Finally, by the same formula we obtained the "corrected" values of $\mathrm{M}_{\mathrm{w}}$. Note that this procedure is able to minimize, at least in part, the magnitude overestimation due to cumulative effects of damage during a sequence. While there is no difference for the case of the 15 January event, the corrected $\mathrm{M}_{\mathrm{w}}$ values for 16 and 25 result increasingly smaller than the ones calculated by the Boxer code.

In order to validate these results, we applied the same procedure in a reverse way, i.e. computing the $\mathrm{M}_{0}$ from the instrumental $\mathrm{M}_{\mathrm{wi}}$ values of the 1968 events listed in Table 6. By adding the moments of the shocks occurring the same day, we obtained a daily cumulative $\mathrm{M}_{0}$; then we added the $\mathrm{M}_{0}$ obtained from the instrumental $\mathrm{M}_{\mathrm{wi}}$ for the following days and summed them to the previous cumulative $\mathrm{M}_{0}$. At the end of each day, the cumulative $\mathrm{M}_{0}$ was converted into the $\mathrm{M}_{\mathrm{wi}}$. These "cumulative" instrumentally derived $\mathrm{M}_{\mathrm{wi}}$ are very similar (inside the error) to the "corrected" $\mathrm{M}_{\mathrm{w}}$ derived from macroseismic data in Table 5. Since 16 January, there is an evident effect of saturation because the cumulative $\mathrm{M}_{\mathrm{wi}}$ nearly reaches the maximum value. 
A reappraisal of the 1968 earthquakes

\begin{tabular}{cccccc} 
Date & $\begin{array}{c}\mathbf{M}_{\mathbf{W}} \\
\text { (from Boxer) }\end{array}$ & Log $\mathbf{M}_{\mathbf{0}}$ & $\begin{array}{c}\mathbf{M}_{\mathbf{0}} \\
(\mathbf{d y n e} \cdot \mathbf{c m})\end{array}$ & $\begin{array}{c}\mathbf{M}_{\mathbf{0}} \\
\text { (by subtraction) }\end{array}$ & $\begin{array}{c}\mathbf{M}_{\mathbf{w}} \\
\text { corrected }\end{array}$ \\
\hline 14 January 1968 & 5.04 & 18.260 & $1.8197 \mathrm{E}+18$ & & 5.04 \\
\hline 15 January 1968 & 5.97 & 19.655 & $4.5186 \mathrm{E}+19$ & $4.33659 \mathrm{E}+19$ & 5.96 \\
\hline 16 January 1968 & 6.17 & 19.955 & $9.0157 \mathrm{E}+19$ & $4.31518 \mathrm{E}+19$ & 5.96 \\
\hline 25 January 1968 & 6.34 & 20.210 & $1.6218 \mathrm{E}+20$ & $2.50186 \mathrm{E}+19$ & 5.80 \\
\hline
\end{tabular}

Table 5. Daily total seismic moment $\mathrm{M}_{0}$ obtained from the macroseismic $\mathrm{M}_{\mathrm{w}}$ through the Hanks and Kanamori [1979] formula: $\mathrm{M}_{\mathrm{W}}=2 / 3 \log \mathrm{M}_{0}-10.7$. The $\mathrm{M}_{\mathrm{W}}$ corrected values represent the final estimates proposed in this study.

\begin{tabular}{|c|c|c|c|c|c|c|}
\hline Date & $\begin{array}{l}\text { Time } \\
\text { (GMT) }\end{array}$ & $\begin{array}{c}\mathrm{M}_{\mathrm{wi}} \\
\text { (instrumental) }\end{array}$ & $\log M_{0}$ & $\begin{array}{c}\mathrm{M}_{0} \\
(\text { dyne } \cdot \mathrm{cm})\end{array}$ & $\begin{array}{c}\mathrm{M}_{0} \\
\text { (cumulative) }\end{array}$ & $\begin{array}{c}\mathrm{M}_{\mathrm{wi}} \\
\text { (cumulative) }\end{array}$ \\
\hline $14 \mathrm{Jan}$ & $13: 15$ & $4.90 \pm 0.24$ & 18.05 & $1.122 \mathrm{E}+18$ & & \\
\hline 14 Jan & $15: 48$ & $4.68 \pm 0.21$ & 17.72 & $5.2481 \mathrm{E}+17$ & $1.64683 \mathrm{E}+18$ & 5.01 \\
\hline $15 \mathrm{Jan}$ & 01:33 & $5.27 \pm 0.21$ & 18.605 & $4.0272 \mathrm{E}+18$ & $5.674 \mathrm{E}+18$ & \\
\hline $15 \mathrm{Jan}$ & 02:01 & $5.67 \pm 0.23$ & 19.205 & $1.6032 \mathrm{E}+19$ & $2.17065 \mathrm{E}+19$ & \\
\hline $15 \mathrm{Jan}$ & $03: 18$ & $4.57 \pm 0.22$ & 17.555 & $3.5892 \mathrm{E}+17$ & $2.20654 \mathrm{E}+19$ & \\
\hline $15 \mathrm{Jan}$ & $13: 42$ & $5.53 \pm 0.59$ & 18.995 & $9.8855 \mathrm{E}+18$ & $3.19509 \mathrm{E}+19$ & \\
\hline $15 \mathrm{Jan}$ & $14: 59$ & $4.79 \pm 0.31$ & 17.885 & $7.6736 \mathrm{E}+17$ & $3.27183 \mathrm{E}+19$ & \\
\hline $15 \mathrm{Jan}$ & $18: 22$ & $4.46 \pm 0.45$ & 17.39 & $2.4547 \mathrm{E}+17$ & $3.29637 \mathrm{E}+19$ & \\
\hline $15 \mathrm{Jan}$ & $22: 19$ & $4.79 \pm 0.26$ & 17.885 & $7.6736 \mathrm{E}+17$ & $3.37311 \mathrm{E}+19$ & 5.89 \\
\hline $16 \mathrm{Jan}$ & $00: 54$ & $4.79 \pm 0.26$ & 17.885 & $7.6736 \mathrm{E}+17$ & $3.44985 \mathrm{E}+19$ & \\
\hline $16 \mathrm{Jan}$ & $13: 10$ & $4.57 \pm 0.35$ & 17.555 & $3.5892 \mathrm{E}+17$ & $3.48574 \mathrm{E}+19$ & \\
\hline $16 \mathrm{Jan}$ & $16: 42$ & $5.27 \pm 0.21$ & 18.605 & $4.0272 \mathrm{E}+18$ & $3.88846 \mathrm{E}+19$ & 5.93 \\
\hline $25 \mathrm{Jan}$ & $09: 56$ & $5.15 \pm 0.21$ & 18.425 & $2.6607 \mathrm{E}+18$ & $4.15453 \mathrm{E}+19$ & \\
\hline $25 \mathrm{Jan}$ & 10:04 & $4.26 \pm 0.27$ & 17.09 & $1.2303 \mathrm{E}+17$ & $4.16683 \mathrm{E}+19$ & \\
\hline $25 \mathrm{Jan}$ & $14: 35$ & $4.46 \pm 0.24$ & 17.39 & $2.4547 \mathrm{E}+17$ & $4.19138 \mathrm{E}+19$ & 5.95 \\
\hline
\end{tabular}

Table 6. Daily total seismic moment $\mathrm{M}_{0}$ obtained from the instrumental $\mathrm{M}_{\mathrm{wi}}$ reported in CPTI15 [Rovida et al., 2016] through the Hanks and Kanamori [1979] formula; the cumulative $\mathrm{M}_{0}$ is obtained by adding $\mathrm{M}_{0}$ of all the shocks preceding a given event. The cumulative $\mathrm{M}_{\mathrm{wi}}$ represents the magnitude theoretically reached by a single shock, which is the sum of $\mathrm{M}_{0}$ of more shocks day by day.

\section{Conclusions}

The 1968 Valle del Belice case study is a clear example of the difficulty in dealing with macroseismic data related to seismic sequences. In particular, the assessment of the macroseismic intensity proved difficult because of (i) a continuously changing damage scenario in the epicentral area owing to the cumulative effects, which only in theory could have been solved by more accurate and timely surveys, and (ii) the degradation of the building resistance (i.e. increase of the vulnerability) due to stronger earthquakes also on the same day. This unavoidably leads to an overestimation of intensity for the later events of the sequence.

The critical analysis of the coeval sources, and particularly the newspapers, together with the direct observation of the building typologies still visible in the abandoned settlements of the epicentral area, has allowed us to correctly apply the EMS-98 and to produce a newly revised intensity dataset. The pattern of intensity observed in different 


\section{Raffaele Azzaro et al.}

localities appears strongly conditioned by the real migration of epicentres during the sequence (see Figure 9), with the consequence that it is impossible to estimate an intensity value that is actually representative of the level of damage due to a single event, but only to assess the cumulative effects.

The strong shocks of the first two days (14 and 15 Jan., $\mathrm{I}_{0} 7$ and 9 respectively) determined heavy damage or destruction in several localities, so that the cumulative scenario essentially became saturated starting from the third day of the sequence (16 Jan., $I_{0} 9-10$ ). This means that these MDPs include not only the summation of the effects produced by the shocks on the same day (14 and 15 Jan.), but also the progressive increase day by day up to the end of the seismic sequence (25 Jan., $\mathrm{I}_{0} 10$ ). As a result, it is evident that since 16 January the MDPs cannot adequately represent the seismic source in terms of magnitude and epicentre.

While critical evaluations about the impact of similar macroseismic parameters on the earthquake catalogues and, hence, seismic hazard are clear, no consolidated solution is adopted in the literature to solve this problem. Here we propose a procedure mainly aimed at minimizing the effect of the magnitude overestimation, through the computation of the total seismic moment $\mathrm{M}_{0}$.

The method consists of "unpacking" the total seismic moment $\mathrm{M}_{0}$ cumulated at the end of the sequence, by subtracting the contribution of each single shocks, to obtain a "corrected" macroseismic magnitude $\mathrm{M}_{\mathrm{w}}$. Results appear effective for the last events of the sequence, with a significant reduction of the magnitude mostly for the 25 January earthquake, from $\mathrm{M}_{\mathrm{w}} 6.34$ to 5.8. This conceptual approach has been checked by comparing the seismic moment from instrumental magnitudes available in the CPTI15 catalogue; the cumulative $\mathrm{M}_{\mathrm{wi}}$ are consistent with the ones obtained by macroseismic data.

Lastly, a final consideration deserves to be made on the use of the number of earthquake victims to corroborate the estimates of intensity, especially for historical events. This practice is extremely misleading, because of the estimate of human losses in a given locality is often uncertain, and the number of deaths depends on a variety of

\begin{tabular}{|c|c|c|c|c|}
\hline Locality & Inhabitants & Victims & Percentage & 25 Jan. intensity \\
\hline Montevago & 3008 & 108 & 3.65 & $9-10$ \\
\hline Gibellina & 6410 & 100 & 1.56 & 10 \\
\hline Santa Ninfa & 5826 & 25 & 0.43 & $8-9$ \\
\hline Salaparuta & 2943 & 19 & 0.64 & 10 \\
\hline Partanna & 13011 & 15 & 0.11 & $8-9$ \\
\hline Santa Margherita & 7811 & 13 & 0.16 & $8-9$ \\
\hline Salemi & 15364 & 5 & 0.03 & 8 \\
\hline Sambuca & 7679 & 5 & 0.06 & $7-8$ \\
\hline Poggioreale & 2698 & 4 & 0.15 & 9 \\
\hline Contessa Entellina & 2669 & 1 & 0.04 & 8 \\
\hline Menfi & 12492 & 0 & 0 & 8 \\
\hline Total & & 290 & & \\
\hline
\end{tabular}

Table 7. Number of victims in the most struck localities of the Valle del Belice; however, there were other fatalities induced by the adverse post-earthquake conditions. Numbers of inhabitants are from ISTAT census in 1961. 
factors. In the case of the 1968 Valle del Belìce earthquakes, for instance, after 15 January the newspapers repeatedly reported 300 deaths in Montevago and 150 in Gibellina, just to consider the most striking cases. On the other hand, official government figures indicated 290 victims: the distribution shown in Table 7 clearly indicates that there is no correlation with the intensity reached at the end of the sequence. One of the reasons, for example in Montevago, is that people were at home during the night of the 15 January when two strong shocks occurred in a time-span of only 30 minutes, since the previous ones on 14 January did not cause any significant damage in this locality.

The reappraisal of the 1968 Valle del Belice seismic sequence confirms that the multiple historical earthquakes need to be considered carefully in terms of seismic sources parameters. Nevertheless, new approaches also in the field of macroseismology, aimed at minimizing the bias due to the overlapping effects, are possible.

Acknowledgements. The authors are very grateful to S. D’Amico for the computation of the macroseismic parameters by the Boxer code, and to the students E. Blanco and D.L. Piluso who, in the framework of their training internships, helped us in the search and analysis of the newspapers. The Biblioteca Centrale della Regione Siciliana "A. Bombace" (Palermo) is acknowledged for permission to use photos from the archive of the newspaper L'Ora. Finally, we wish to thank Filippo Bernardini and Paola Cusano for their useful insights and comments, which helped improve the manuscript. Thanks to S. Conway for revising this text This study has partially benefited from funding provided by the Italian Presidenza del Consiglio dei Ministri - Dipartimento della Protezione Civile (DPC). This paper does not necessarily represent DPC official opinion and policies..

\section{References}

AA.VV. (1968). L'opera di Protezione Civile nella Sicilia occidentale colpita dal terremoto 14 gennaio - 31 marzo 1968. Quaderni di Protezione Civile, numero speciale autunno, 68.

Azzaro, R., M. Cascone and A. Amantia (2020). Earthquakes and ghost towns in Sicily: from the Valle del Belìce in 1968 to the Val di Noto in 1693. The first stage of the virtual seismic itinerary through Italy. Ann. Geophys., 66, doi:10.4401/ag-8175.

Barbano, M.S., M. Cosentino, G. Lombardo and G. Patané (1980). Isoseismal maps of Calabria and Sicily earthquakes (Southern Italy). CNR-PFG, 341, Catania, 116 pp.

Bosi, C., R. Cavallo and M. Manfredini (1968). Il terremoto della Valle del Belice del gennaio 1968, in "Rassegna dei Lavori Pubblici”, n.2, febbraio 1968, Roma.

Bosi, C., R. Cavallo and V. Francaviglia (1973). Aspetti geologici e geologico-tecnici del terremoto della Valle del Belíce del 1968. Mem. Soc. Geol. It., 12, 81-130.

Bottari, A. (1973). Attività sismica e neotettonica della Valle del Belice. Ann. Geofis., 26 (1), 55-84.

Cannata, D., M. Costantino, A. D’Amore, G. Gregorio, M. Irti, A. Pasta, D. Priolo, V. Stura and G. Miglietti (1968). Missione di studio nelle zone terremotate della Sicilia Occidentale. In “L'industria delle costruzioni”. Rivista tecnica dell'ANCE”, settembre-ottobre 1968, Roma, 11-50.

Cartoline macrosismiche (1968). Archivio macrosismico INGV.

Cosentino, P. and A. Mulone (1985). The Belíce earthquake of January 16, 1968. In Atlas of isoseismal maps of Italian earthquakes, D. Postpischl (Ed.), CNR, Quad. Ric. Scie., 114B, 150-151.

De Panfilis, M. and L. Marcelli (1968). Il periodo sismico della Sicilia occidentale iniziato il 14 Gennaio 1968. Ann. Geofis., 21, 79 pp.

Filangeri, C. (2001). Ricordi tra immagini e ... versi. Ed. Associazione Culturale Filangeri di Cutò, S. Margherita di Belìce, $191 \mathrm{pp}$.

Gangemi, G. and R. La Franca (1979). Centri storici di Sicilia. Inventario di protezione dei sistemi urbani delle provincie di Trapani, Agrigento, Caltanissetta, Enna. Vittorietti (Ed.,)., Palermo, I, 98 pp.

Gasperini, P., G. Vannucci, D. Tripone and E. Boschi (2010). The location and sizing of historical earthquakes using the attenuation of macroseismic intensity with distance. Bull. Seism. Soc. Am., 100, 2035-2066.

Graffagnino, B. (1992). Salaparuta ieri e oggi ‘92. Arti Grafiche Siciliane, Palermo, 588 pp.

Graziani, L., A. Tertulliani, A. Maramai, A. Rossi and L. Arcoraci (2017). The 1984 Abruzzo-Latium seismic sequence: reappraisal of the existing macroseismic datasets according to the EMS98. J. Seismol., 21(1), 1-9, 


\section{Raffaele Azzaro et al.}

doi:10.1007/s10950-017-9663-3.

Graziani, L., S. Del Mese, A. Tertulliani, L. Arcoraci, A. Maramai and A. Rossi (2019). Macroseismic assessment (EMS98) of damage progression during the 2016-17 seismic sequence in Central Italy, Bull. Earthq. Eng., https://doi.org/10.1007/s10518-019-00645-w.

Grimaz, S. and P. Malisan (2016). How could cumulative damage affect the macroseismic assessment? Bull. Earthq. Eng. 15(6), 2465-2481, DOI:10.1007/s10518-016-0016-3.

Grünthal, G. (Ed.). 1998. European Macroseismic Scale 1998 (EMS-98). European Seismological Commission, sub commission on Engineering Seismology, Working Group Macroseismic Scales. Conseil de l'Europe, Cahiers du Centre Européen de Géodynamique et de Séismologie 15. Luxembourg, pp. 99, http://www.ecgs.lu/cahiers-bleus/.

Guidoboni, E., G. Ferrari, D. Mariotti, A. Comastri, G. Tarabusi, G. Sgattoni and G. Valensise (2018). CFTI5Med, Catalogo dei Forti Terremoti in Italia (461 a.C.-1997) e nell'area Mediterranea (760 a.C.-1500). INGV, http://storing.ingv.it/cfti/cfti5/

Guidoboni, E. and G. Valensise (2011). Il peso economico e sociale dei disastri sismici in Italia negli ultimi 150 anni, 1861-2011. Bonomia University Press, Bologna, 550 pp., ISBN 978-88-7395-683-9.

Haas, J. E. and R.S. Ayre (1969). The western Sicily earthquake of 1968. Committee on Earthquake Engineering Research, National Academy of Sciences, Washington, D. C., 77 pp.

Hanks, T. C. and H. Kanamori (1979). A moment magnitude scale. J. Geoph. Res., 84 (B5), 2348-50.

Locati, M., R. Camassi, A. Rovida, E. Ercolani, F. Bernardini, V. Castelli, C.H. Caracciolo, A. Tertulliani, A. Rossi, R. Azzaro, S. D'Amico, S. Conte and E. Rocchetti (2016). DBMI15, the 2015 version of the Italian Macroseismic Database. Istituto Nazionale di Geofisica e Vulcanologia. http://doi.org/10.6092/INGV.IT-DBMI15

Marino, G.C. (1968). ‘68 terremoto in Sicilia. Andò Editori, Palermo, 140 pp.

Rossi, A., A. Tertulliani, R. Azzaro, L. Graziani, A. Rovida, A. Maramai, V. Pessina, S. Hailemikael, G. Buffarini, F. Bernardini, R. Camassi, S. Del Mese, E. Ercolani, A. Fodarella, M. Locati, G. Martini, A. Paciello, S. Paolini, L. Arcoraci, C. Castellano, V. Verrubbi and M. Stucchi (2019). The 2016-2017 earthquake sequence in Central Italy: macroseismic survey and damage scenario through the EMS-98 intensity assessment. Bull. Earth. Eng., 17 (5), 2407-2431, https://doi.org/10.1007/s10518-019-00556-w.

Rovida, A., M. Locati, R. Camassi, B. Lolli and P. Gasperini P. (2016). CPTI15, the 2015 version of the Parametric Catalogue of Italian Earthquakes. INGV, doi:http://doi.org/10.6092/INGV.IT-CPTI15.

Tertulliani, A., L. Arcoraci, M. Berardi, F. Bernardini, B. Brizuela, C. Castellano, S. Del Mese, E. Ercolani, L. Graziani, A. Maramai, A. Rossi, M. Sbarra and M. Vecchi (2012). Emilia 2012 sequence: the macroseismic survey, in "The Emilia (northern Italy) seismic sequence of May-June, 2012: preliminary data and results”, M. Anzidei, A. Maramai and P. Montone (Eds), Ann. Geoph., 55 (4), 2012; doi:10.4401/ag-6140.

Traina, M. (1978). Valle del Belice (introduzione alla storia di 10 anni di terremoto). Tip. Fiamma Serafica, Palermo, $414 \mathrm{pp}$.

Valle, P.E. (1969). Tentativo di controllo del periodo sismico siciliano iniziato il 14 Gennaio 1968, Annali di Geofisica, 22, 57-84.

\section{Other sources consulted}

\section{Local historiographic studies}

AA.VV. (1969). Terremoto in Sicilia. Lintervento del Ministero dei lavori Pubblici per le zone sinistrate. Litopress, $41 \mathrm{pp}$. Aloisio, F. (1986). Storia di Poggioreale (Sicilia). Tip. Priulla, Palermo, 318 pp.

Cangelosi, L. (1977). Addio, Gibellina. Arti Grafiche Campo, Alcamo (TP), 155 pp.

Cusumano, A. (2003). La strada maestra. Memoria di Gibellina. Comune di Gibellina, Graf. Campo, Alcamo, 130 pp. Ferina, S. L'Abbazia di Santa Maria del Bosco. Edited by Archdiocese of Monreale (Palermo).

Giuffrida, G. (1998). Montevago.

Scuderi, S. and G. Scuderi (2003). Santa Margherita di Belìce nella storia siciliana. Genesi del Gattopardo. Scuderi (Ed.), S. Margherita, 723 pp.

Vella, E. (2003). Poggioreale di Sicilia tra civiltà contadina e odierna società. Prova d'autore Editore, Tip. Artestampa, Catania, 199 pp. 


\section{Newspapers}

ANSA, 1968.01.14, Palermo

ANSA, 1968.01.15, Palermo

Corriere della Sera del lunedi, 1968.01.15, a. 7 n. 2, Milano

Corriere della Sera, 1968.01.16, a. 93 n. 13, Milano

Corriere della Sera, 1968.01.18, a. 93 n. 15, Milano

Corriere della Sera, 1968.01.19, a. 93 n. 16, Milano

Corriere della Sera, 1968.01.20, a. 93 n. 17, Milano

Corriere della Sera, 1968.01.21, a. 93 n. 18, Milano

Corriere della Sera del lunedi, 1968.01.22, a. 7 n. 3, Milano

Corriere della Sera, 1968.01.23, a. 93 n. 19, Milano

Corriere della Sera, 1968.01.24, a. 93 n. 20, Milano

Corriere della Sera, 1968.01.25, a. 93 n. 21, Milano

Corriere della Sera, 1968.01.26, a. 93 n. 22, Milano

Corriere della Sera, 1968.01.27, a. 93 n. 23, Milano

Corriere della Sera, 1968.01.28, a. 93 n. 24, Milano

Corriere della Sera, 1968.01.30, a. 93 n. 25, Milano

Corriere della Sera, 1968.01.31, a. 93 n. 26, Milano

Corriere della Sera, 1968.02.08, a. 93 n. 33, Milano

Giornale di Sicilia, 1968.01.15, a.108, n.14, Palermo Giornale di Sicilia, 1968.01.16, a.108, n.15, Palermo Giornale di Sicilia, 1968.01.17, a.108, n.16, Palermo Giornale di Sicilia, 1968.01.18, a.108, n.17, Palermo Giornale di Sicilia, 1968.01.20, a.108, n.19, Palermo Giornale di Sicilia, 1968.01.21, a.108, n.20, Palermo Giornale di Sicilia, 1968.01.22, a.108, n.21, Palermo Giornale di Sicilia, 1968.01.23, a.108, n.22, Palermo Giornale di Sicilia, 1968.01.24, a.108, n.23, Palermo Giornale di Sicilia, 1968.01.25, a.108, n.24, Palermo Giornale di Sicilia, 1968.01.26, a.108, n.25, Palermo Giornale di Sicilia, 1968.01.27, a.108, n.26, Palermo

Il Piccolo, Trieste

La Sicilia, 1968.01.15, a.24, n.14, Catania La Sicilia, 1968.01.16, a.24, n.15, Catania La Sicilia, 1968.01.17, a.24, n.16, Catania La Sicilia, 1968.01.18, a.24, n.17, Catania La Sicilia, 1968.01.19, a.24, n.18, Catania La Sicilia, 1968.01.20, a.24, n.19, Catania La Sicilia, 1968.01.21, a.24, n.20, Catania La Sicilia, 1968.01.22, a.24, n.21, Catania La Sicilia, 1968.01.24, a.24, n.23, Catania La Sicilia, 1968.01.25, a.24, n.24, Catania La Sicilia, 1968.01.26, a.24, n.25, Catania La Sicilia, 1968.01.27, a. 24, n.26, Catania La Sicilia, 1968.01.28, a.24, n.27, Catania La Sicilia, 1968.01.30, a.24, n.29, Catania La Sicilia, 1968.02.02, a.24, n.32, Catania La Sicilia, 1968.02.10, a.24, n.41, Catania 


\section{Raffaele Azzaro et al.}

La Sicilia, 1968.02.11, a.24, n.42, Catania La Sicilia, 1968.02.13, a.24, n.44, Catania La Sicilia, 1968.02.20, a.24, n. 51, Catania La Sicilia, 1968.03.03, a.24, n.63, Catania La Sicilia, 1968.03.06, a.24, n.66, Catania La Sicilia, 1968.03.31, a.24, n.91, Catania

La Stampa, 1968.01.15, a.102, n.13, Torino La Stampa, 1968.01.16, a.102, n.14, Torino La Stampa, 1968.01.18, a.102, n.16, Torino La Stampa, 1968.01.19, a.102, n.17, Torino La Stampa, 1968.01.20, a.102, n.18, Torino La Stampa, 1968.01.21, a.102, n.19, Torino La Stampa, 1968.01.23. a.102, n.21, Torino La Stampa, 1968.01.24. a.102, n.22, Torino La Stampa, 1968.01.25. a.102, n.23, Torino La Stampa, 1968.01.26. a.102, n.24, Torino La Stampa, 1968.01.27. a.102, n.25, Torino La Stampa, 1968.02.01. a.102, n.30, Torino La Stampa, 1968.02.02. a.102, n.31, Torino La Stampa, 1968.02.03. a.102, n.32, Torino La Stampa, 1968.02.06, a.102, n.35, Torino La Stampa, 1968.02.09, a.102, n.38, Torino La Stampa, 1968.02.11, a.102, n.40, Torino La Stampa, 1968.02.13, a.102, n.42, Torino La Stampa, 1968.02.17, a.102, n.47, Torino La Stampa, 1968.03.23, a.102, n.81, Torino La Stampa, 1968.04.02, a.102, n.91, Torino La Stampa, 1968.04.07, a.102, n.95, Torino

L’Ora, 1968.01.15/16, a.69, n.12, Palermo L’Ora, 1968.01.16/17, a.69, n.13, Palermo L’Ora, 1968.01.18/19, a.69, n.15, Palermo L’Ora, 1968.01.19/20, a.69, n.16, Palermo L’Ora, 1968.01.20/21, a.69, n.17, Palermo L’Ora, 1968.01.22/23, a.69, n.18, Palermo L’Ora, 1968.01.23/24, a.69, n.19, Palermo L’Ora, 1968.01.25/26, a.69, n.21, Palermo L’Ora, 1968.01.26/27, a.69, n.22, Palermo L’Ora, 1968.01.27/28, a.69, n.23, Palermo L’Ora, 1968.01.29/30, a.69, n.24, Palermo L’Ora, 1968.01.30/31, a.69, n.25, Palermo L'Ora, 1968.01.31/02.01, a.69, n.26, Palermo L’Ora, 1968.02.1/2, a.69, n.27, Palermo L’Ora, 1968.02.3/4, a.69, n.29, Palermo

Telestar, 1968.01.15, a.IV, n. 12, Palermo Telestar, 1968.01.16, a.IV, n. 13, Palermo Telestar, 1968.01.17, a.IV, n. 14, Palermo Telestar, 1968.01.18, a.IV, n. 15, Palermo Telestar, 1968.01.19, a.IV, n. 16, Palermo Telestar, 1968.01.20, a.IV, n. 17, Palermo 


\section{A reappraisal of the 1968 earthquakes}

Video

RAI, Radiotelevisione Italiana. Collection of TV reports, 1968. RAI Teche, Palermo, duration 108 minutes, also available on http://www.teche.rai.it.

Belice, 35 anni dopo. Directed by R. Vitellaro, Larcadarte production, duration 46 minutes.

Omaggio al paese del Gattopardo. Directed by M. Taiani, duration 27 minutes.

Poggioreale di Sicilia, “ritorni”. Directed by P. Duca, PIANOSEQUENZA production, duration 37 minutes.

Poggioreale, nascita di un paese. Directed by A. Vergine, Diario Italiano production, duration 53 minutes.

Santa Margherita Belice...tra memoria storica e orizzonti di legalità. Directed by M. Taiani, duration 33 minutes. 